\title{
Resilience toward Volcanic Eruptions: Risk Perception and Disaster Microinsurance in Yogyakarta, Indonesia
}

\author{
Aloysius Gunadi Brata ${ }^{1}\left(\mathbb{D}\right.$, , Henri L. F. de Groot ${ }^{2}$, Piet Rietveld ${ }^{2,+}$, Budy P. Resosudarmo ${ }^{3, *(D)}$ and Wouter Zant ${ }^{4}$ (D) \\ 1 Department of Economics, Atma Jaya Yogyakarta University, Yogyakarta 55281, Indonesia; \\ aloy.gb@gmail.com \\ 2 Department of Spatial Economics, VU University Amsterdam, 1081 HV Amsterdam, The Netherlands; \\ h.l.f.de.groot@vu.nl \\ 3 Arndt-Corden Department of Economics, Australian National University, Canberra, ACT 2601, Australia \\ 4 Department of Economics, VU University Amsterdam, 1081 HV Amsterdam, The Netherlands; \\ wouter.zant@vu.nl \\ * Correspondence: budy.resosudarmo@anu.edu.au; Tel.: +61-2-6125-2244 \\ + Piet Rietveld has passed away.
}

Citation: Brata, A.G.; de Groot, H.L.F.; Rietveld, P.; Resosudarmo, B.P.; Zant, W. Resilience toward Volcanic Eruptions: Risk Perception and Disaster Microinsurance in Yogyakarta, Indonesia. Sustainability 2021, 13, 8912. https://doi.org/ $10.3390 /$ su13168912

Academic Editor: Wen Cheng Liu

Received: 15 June 2021

Accepted: 30 July 2021

Published: 9 August 2021

Publisher's Note: MDPI stays neutral with regard to jurisdictional claims in published maps and institutional affiliations.

Copyright: (c) 2021 by the authors. Licensee MDPI, Basel, Switzerland. This article is an open access article distributed under the terms and conditions of the Creative Commons Attribution (CC BY) license (https:/ / creativecommons.org/licenses/by/ $4.0 /)$.

\begin{abstract}
Disaster microinsurance has been argued to enhance people's resilience toward natural hazards. In developing countries, however, the uptake of this insurance scheme has been limited. This paper investigates the influence of the perception of disaster risks on the probability of local people participating in a hypothetical disaster microinsurance scheme. We use household data to assess a specific disaster risk, notably the risk of an eruption of the Mount Merapi in Yogyakarta. We find that this perception positively influences the interest to participate in disaster microinsurance. We also find that insurance literacy has a strong positive relationship with the respondent's interest to participate in disaster microinsurance.
\end{abstract}

Keywords: resilience; disaster; risk perception; volcanic eruptions; microinsurance

\section{Introduction}

Disaster microinsurance can play an important role for low-income households, particularly in enhancing their resilience toward natural hazards. This insurance is a specific type of microinsurance that can be defined as an insurance for low-income people, to help them to manage risks and vulnerability toward local natural shocks [1-4]. In other words, disaster microinsurance is a type of risk transfer mechanism specifically designed for low-income people who live in disaster-prone areas. The product of this microinsurance may cover financial losses caused by a large natural hazard event in terms of income, house, livestock, or other crops. This microinsurance is also known as a component of integrated disaster risk management frameworks that involve risk reduction, disaster preparedness, and risk transfer [5].

Large natural hazard events in recent years, such as the Aceh tsunami in 2004, have triggered discussions on the possibility to introduce disaster microinsurance in Indonesia, but this is still a hardly explored field [2,6,7]. People in Indonesia are yet to be exposed to different types of disaster microinsurance that they could buy, although disasters have been an important risk that can affect household welfare [8,9]. For the limited insurance options available, the uptake has been poor [2]. Other studies also indicate that the rate of participation in microinsurance in developing countries is low [4,10-12].

Promoting disaster microinsurance requires a better understanding of what the main determinants for participating in this insurance are. One possible determinant is people's perception of disaster risks relative to their living location $[13,14]$. This risk perception is important, since it could indicate households' willingness to invest beyond their usual patterns [15]. However, although large populations in Indonesia face disasters in their daily 
life, the link between perception of risk and disaster microinsurance is still rarely studied. One of the few conducted is by Viverita et al. [8], assessing whether natural hazards are the most common risk faced by individuals or households. This study also does not focus on a specific disaster, although it has been argued that each natural hazard might bring a specific risk.

The goal of this paper, hence, is to determine whether or not a specific disaster risk perception significantly influences the probability of household living in this disaster-prone area to participate in a disaster microinsurance, a scheme that could improve households resilience toward the disaster. To achieve this goal, this paper uses the case study of a hypothetical disaster microinsurance scheme and the disaster risk perception of Merapi volcano eruptions in Yogyakarta.

Yogyakarta is a small province, with an area of about $3100 \mathrm{~km}^{2}$, on the Indonesian island of Java. Its capital is called the city of Yogyakarta (Figure 1). The urban areas of the province are centered on the city of Yogyakarta and its surroundings. The Merapi volcano is one of the most active volcanoes in Indonesia, located just 25-30 km north of the city of Yogyakarta. Historically, this volcano has erupted every four years, and the eruption in 2010 was the largest eruption in more than a century $[16,17]$. The eruption in 2010 affected four districts, killed 386 people, and caused losses and damage in the order of US $\$ 403$ million [18]. Thousands of houses in the Cangkringan subdistrict in the Yogyakarta province were destroyed.

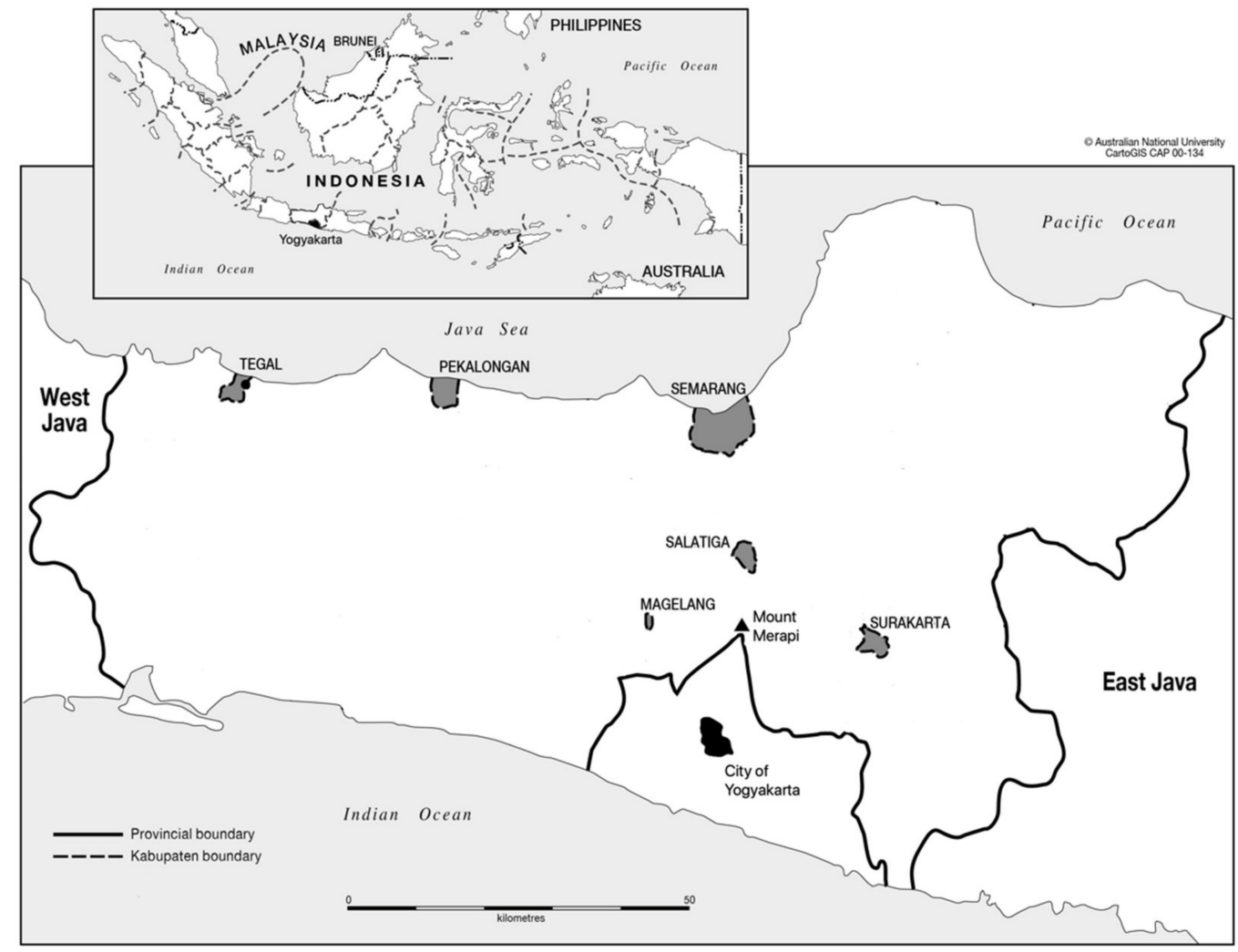

Figure 1. Yogyakarta and the Mount Merapi.

This paper utilizes data at the household level, collected by a joint team from Gadjah Mada University of Indonesia and the Australian National University (ANU)'s Indonesia Project around 18 months after the 2010 Merapi eruption, when some respondents were still living in temporary shelters. The data set contains people's response on their willingness to participate in a hypothetical disaster microinsurance. Using this data set, we then statistically tested whether the perception of disaster risks related to the Merapi volcano's eruption influences the probability of local people participating in a hypothetical disaster 
microinsurance scheme. This study is expected to provide evidence on this prospective countermeasure to natural hazard risks.

The result of this study shows, in fact, that the households' perception of disaster risks is a significant determinant of demand for disaster microinsurance. Consequently, local people's perception of natural hazard risks should be taken into account in designing and proposing a specific insurance scheme for people living in areas vulnerable to natural hazards.

In the analysis, we also introduce several socio-economic characteristics of households, such as insurance literacy, health risk, and local social networks measured by their connection with village officials, membership of local associations, and access to house disaster relief. Insurance literacy has a strong and significant relationship with the respondents interest to participate in disaster microinsurance. Other important variables are access to disaster relief for housing, membership of local associations, and health risk.

The organization of this paper is as follows. The next section presents a literature review where we discuss previous works on disaster risk perception and other determinants influencing the decision to take a disaster microinsurance. The literature review is followed by the sections on the methodology and the results, where we present the methodology utilized and the results of our analysis. Finally, the paper ends with a conclusion section.

\section{Literature Review}

\subsection{Perception of Risks}

Scientists define risk as 'hazard times exposure equals consequence, while the average person defines risk as 'the probability of something bad happening' [19]. This implies that the difference between these two risks is also important, as it can sometimes create further risks. In the context of natural hazard events, some studies present interesting results. Comparing the perceived risks and frequency of disasters from the survey results and the historical records of disasters, Wang et al. [20] argue that Chinese people, in general, have a correct perception of the hazards in the areas in which they live in. This indicates that there is no substantial gap between experts and lay people in assessing disaster risk. On the basis of their study of a flood-prone area in Slovenia, Brilly and Polic [21] show that the experience of floods influences the perceived threat and concern related to them. They also find that people are aware of the importance of insurance against floods, which results in an increase in the rate of insurance participation. Siegrist and Gutscher [22] confirm that lay people's risk perceptions and experts' risk assessment of flooding risks in Switzerland are correlated, but the strength of this relationship differs across regions.

The perception of risk, according to Slovic [23] and Renn [24,25], is basically known as the subjective judgement that people make about the characteristics and severity of a risk. Therefore, on average, intuitive risk judgments are important for people in evaluating hazards [23]. This highly personal process of decision making is based on, among many other factors, an individual's frame of reference developed over a lifetime [19]. Some studies underline the role of locational factors, as well as the experience of past shocks, on people's perception of exposure to risk in disasters related to natural hazard events $[22,26,27]$ that could in turn affect households' decisions, such as that of participating in, for example, microinsurance [4]. This means that, when the disaster shocks change people's perception of risk, then their risk-taking behavior will also be affected depending on the impact of the shocks on income and wealth. As is commonly known, wealth is negatively associated with risk aversion. When a disaster negatively changes the wealth of a household, then this household will possibly be more risk-averse, whereby insurance may play a role to avoid risk-related disasters.

Based on this framework, we can expect that people who face natural hazard risks may be aware of important strategies in which disaster microinsurance is a promising option with several benefits: reducing vulnerability; being in a better position to cope with risk; protecting living standards; and complementing any social security system [2]. As noted by Kelman and Mather [28], one of the options for dealing with environmental 
hazards is to live with the hazards and risks, implying that livelihoods are intertwined with environmental threats and opportunities.

Empirical work, however, could not yet confirm the relationship between perception of risk and willingness to take up any disaster microinsurance. Xu et al. [13], in the case of the 2008 Wenchuan earthquake, observe that households' risk perceptions and livelihood capital are the most important factors affecting their willingness to purchase earthquake disaster insurance. Royal and Walls [14], in a survey among Maryland floodplain residents, show that stated risk perceptions predict voluntary flood insurance take-up. Fier and Carson [29] find a statistically significant relationship between natural hazard events and the demand for life insurance across states in the US, confirming that natural hazards affect not only property insurance but also life insurance. In a case study on the risk of flooding and cyclones in Bangladesh, Akter et al. [30] find that the return period of natural hazards and the distance at which people live from the river significantly explain the household decision to participate in insurance.

Naoi et al. [31], on the other hand, find that many households in Japan do not buy earthquake insurance, since it is too expensive, and this insurance does not reflect regional differences in earthquake risks. Longwell [32] suggests that the lack of equity and a certain bias in the perceived earthquake risk among Californians tend to lower the participation rate in earthquake insurance. Wang et al. [20], however, emphasize that disaster insurance participation is not directly influenced by this perceived risk of hazards when people expect the government to provide support.

\subsection{Other Determinants}

In an ideal situation (for instance, a perfect insurance market), one may assume that the questions about the need for insurance and the interest in participating in disaster microinsurance can be directed to respondents who have a perfect knowledge of insurance. However, it is difficult to expect that respondents would have such a perfect knowledge, even in developed countries. For instance, McCormack et al. [33] find that a sizable proportion of Medicare beneficiaries in Kansas City are unaware of some basic and critical aspects related to cost, coverage, and supplemental insurance options, although they are already informed about some elements of the Medicare program. In a recent study on health insurance, Paez et al. [34] state that one factor that may determine whether consumers select a suitable health plan and use health insurance to their best advantage is health insurance literacy. This also leads to the assessment of the influence of insurance literacy on the household decision to participate in disaster microinsurance [20].

As regards household risk factors, we note the influence of having children [35] on the probability of buying disaster microinsurance. Households with children are usually assumed to be more vulnerable to risks, and therefore they may have more interest in participating in disaster microinsurance. We can also include smoking behavior as a proxy for health status. A poor health (higher health risk) may have a negative effect on household expenditure by increasing the health costs of illness and reducing the household's capacity to earn income when the head of the household, as the main income earner, has health problems. This is in line with the available literature on health insurance, i.e., a correlation between health risk and health insurance demand [36]. Therefore, a higher smoking indicator index indicates a higher health risk, which might positively influence household participation in disaster microinsurance.

Social networks can also play a role as a channel to other disaster-coping mechanisms, and can therefore influence the participation in insurance. Having a close relationship with relatives will provide an opportunity to get informal support that, in turn, may reduce the household's probability of participating in disaster insurance. It is interesting that, in his study on reconstruction funds in Fiji, Takasaki [37] finds that traditional kin elites who have power, such as the chief's clans, receive benefits sooner than others in recipient villages. Therefore, it is possible to expect that people who have relatives who are known as village elites (like members of the village government) will have better access to this 
relief and will negatively respond to disaster microinsurance. In addition, membership of local associations may also reduce the likelihood of a household participating in disaster insurance [38]. Some types of local associations certainly depend on location: for instance, local associations related to agricultural activities are important for villagers in rural areas.

Disaster relief is also a coping alternative, so that access to ex-post disaster relief $[20,30,32]$ can be expected to have a negative influence on the participation in disaster microinsurance. Meanwhile, liquid assets may play a role as a self-insurance. Therefore, for households with liquid assets, participating in disaster insurance is less urgent. Finally, households' ability to pay their monthly premium for disaster microinsurance may affect participation in disaster microinsurance (for instance, [30]). Yet it is also possible that higher income negatively affects participation in this insurance when higher income reflects the capacity to self-insure in the same way as liquid assets.

\section{Methodology}

\subsection{Hypotheses}

The main hypothesis of the study in this paper is that households who have a higher risk perception that their place of residence is in a disaster-prone area of the Merapi volcano tend to be interested in participating in disaster microinsurance. Other hypotheses are related to other important determinants of disaster microinsurance demand. First, we would like to argue that households with better literacy of insurance tend to be interested in participating in disaster microinsurance. The more they know the benefits of the insurance, the more they are interested to join. Second, households with an indicator of high health risk (i.e., a long habit smoker as the head of household) tend to be interested in participating in disaster microinsurance. This hypothesis is aligned with the literature on health insurance, i.e., a correlation between health risk and health insurance demand [36]. Third, households with young children tend to be interested in participating in disaster microinsurance. Children are prone to any disaster. Hence, the heads of households would be interested to protect their children from disasters [35]. Finally, households with stronger local social networks are less interested in participating in disaster microinsurance. Having stronger networks is an indication of a stronger coping ability and so is typically seen as an alternative of any insurance. Local social networks in this paper are measured by (1) having relatives who are village officials, (2) membership of local associations (farmer and breeder), and (3) having access to house disaster relief.

We test the above hypothesis by controlling households' welfare, i.e., income and assets.

\subsection{Data Sources and Description}

For the purpose of this study, we use data at the household level collected by a joint team of the Gadjah Mada University of Indonesia and the Indonesia Project of the ANU in 2012. This survey was conducted to investigate the impact of the Merapi eruption in 2010 on the welfare of people living around the volcano, especially those people who were affected by the eruption. The sample frame used in this survey consists of the lists of households in the Cangkringan and the Prambanan subdistricts, based on the 2010 Population Census, and was provided by the local government offices. The Cangkringan subdistrict is situated closest to the summit of Merapi volcano, while the Prambanan subdistrict is quite far from the volcano. However, both are relatively close to the city of Yogyakarta. Therefore, the surveyed households in Prambanan can be used as the control group. According to the official data at the subdistrict level, there are 8778 households in the Cangkringan subdistrict in 2010, and about $36 \%$ of them were affected by the Merapi eruption in 2010. Relatively fewer houses were affected by this eruption in the Prambanan subdistrict.

There are five villages in the Cangkringan subdistrict, but the team randomly chose three villages: Glagaharjo, Kepuharjo, and Umbulharjo. The number of households in these villages are 1163,920 , and 1379 , respectively, or $40 \%$ of the total households in the Cangkringan subdistrict. Most of the inhabitants of these three villages were evacuated during the volcanic crisis in 2010. Random sampling was used to create 300 samples, 
about $3.4 \%$ of the total households in the three villages; 20 of them were used to test the questionnaire, and the rest were used for interviews. In the Prambanan subdistricts, 80 households were randomly selected from 191 households in the Jamusan subvillage in the Bokoharjo village. Ultimately, the total number of households that could be traced for an interview was 276 ( 216 households in the Cangkringan and 60 households in the Prambanan subdistricts). The interviews were also conducted in the shelters for respondents who were still evacuated. We excluded five respondents from the Cangkringan subdistrict because of missing information and outliers for our relevant variables, resulting in 271 observations.

Demographic characteristics of households in the final sample are as follows. As many as $48(17.7 \%)$ of them have a female as the household head. Most household heads are married $(79.7 \%)$, and the rest are single or divorced. Classifying these samples based on the highest education level obtained by household heads, as many as $56(20.7 \%)$ of them finished senior high school or had at least 12 years of schooling. In terms of the age of household heads, they can be classified into five groups: 29 years old or below $(8.1 \%)$, $30-39$ years old $(21.8 \%), 40-49$ years old $(20.3 \%), 50-59$ years old $(18.1 \%)$, and 60 years old or above $(31.7 \%)$. This background information indicates that most of the participants in this study are in their productive age, and their education is relatively high.

Figure 2 shows that house damage has been identified by respondents as their main concern. As is known, thousands of houses were destroyed by the 2010 eruption. The second main concern are health problems. These concerns suggest that disaster insurance can play a role in dealing with the negative consequences of the risk of eruption for housing and health.

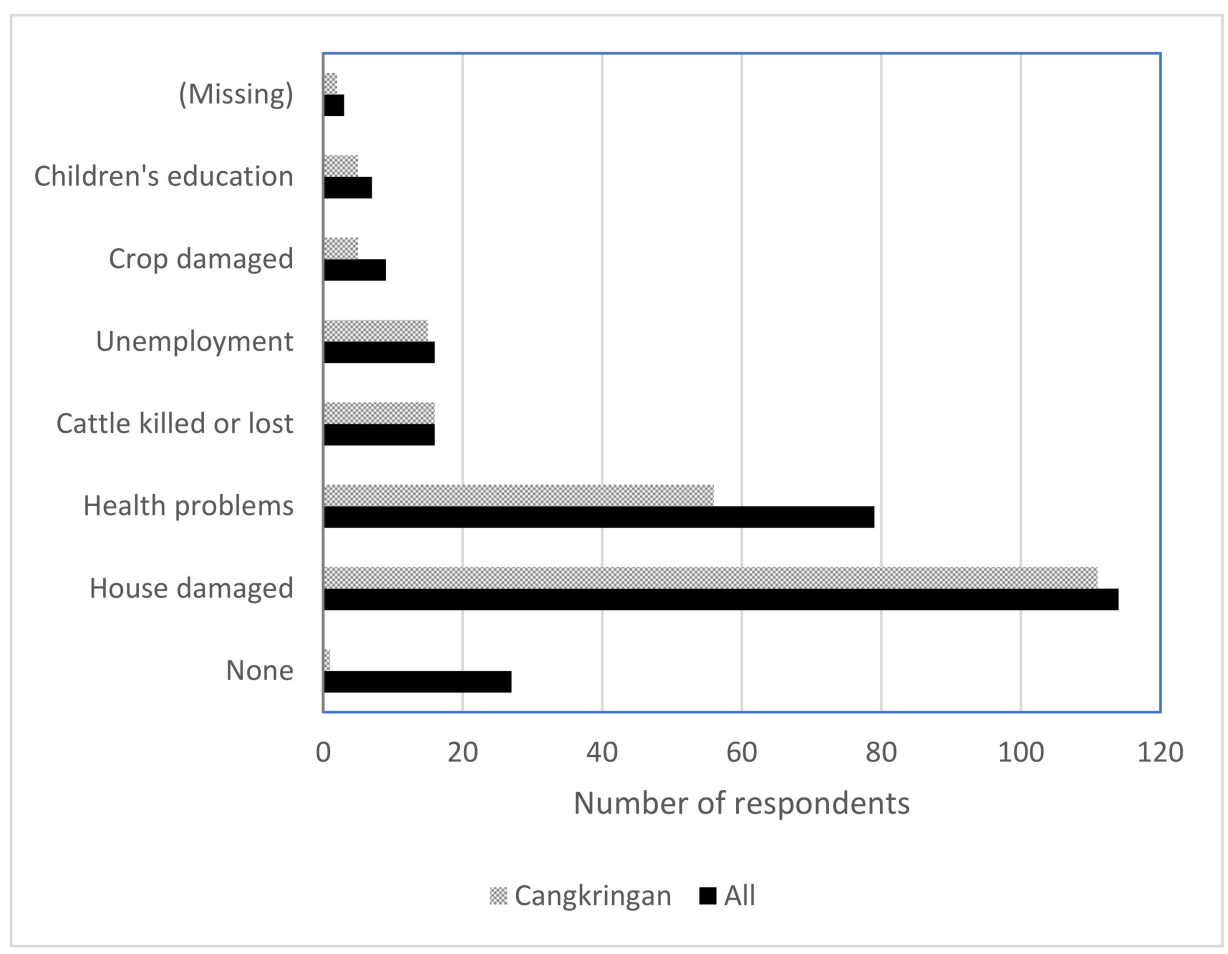

Figure 2. Main concerns related to the impacts of the eruption selected by respondents.

From the survey, we find that $28 \%$ of the respondents (or 75 respondents) stated that they were interested in participating in a hypothetical disaster microinsurance scheme (see: Appendix B for definition and questions related to the knowledge of insurance and participation in disaster microinsurance). This figure must be interpreted with care, since an actual disaster microinsurance scheme has not been developed for the Merapi eruption risk. It addresses the barrier that people must pass before they actually take the decision to sign up for this type of insurance scheme. The final decision will depend on obvious factors such as the cost of the insurance premium, the amount of money paid by the insurance 
company in case of a disaster, the details of the insurance contracts, and so forth. Thus, it is plausible that the actual response to an insurance scheme like the one discussed here would be smaller than the initial response we observe in the present study.

We can relate the respondents' attitude toward the microinsurance scheme to their disaster risk assessment. In general, it is difficult to measure the perception of risk. In this paper, we identified the respondents' perception of risk based on their response to the question: 'Was your place of residence in a disaster-prone area (for any natural hazard events)?'. This question assessed the respondents' place of residence during the 2010 eruption. Based on their response, we classified respondents into two groups of risk perception: 'living in disaster-prone area' and 'not living in disaster-prone area' (see: Appendix A for a detailed description in constructing households' perceptions of risk). Individuals, hence, can have different perceptions of risk, although they live in the same area. This is due to other factors that may contribute to how people identify their risk perception.

Using our classification of risk perception, we present the distribution of respondents based on risk assessments (Table 1). In general, this table shows that only around 27-30\% of respondents who were classified as facing natural hazard risks responded that they were interested in participating in disaster microinsurance. However, respondents who were 'not facing disaster risks' also showed a relatively similar response rate. Around $24-29 \%$ of them responded that they were interested in disaster microinsurance, indicating that they also realized the negative impacts of the eruption, even though they did not live in an area vulnerable to the Merapi eruption. This implies that the development of disaster insurance programs should also consider the surroundings of the area vulnerable to the disaster. In addition, Table 1 also provides the percentage of those interested in disaster microinsurance for respondents whose self-risk assessment matches the experts' assessment. It shows similar results, indicating disaster risk influences the participation in a disaster microinsurance scheme, although it is not so large.

Table 1. Risk assessments and response to disaster microinsurance.

\begin{tabular}{|c|c|c|}
\hline \multicolumn{2}{|c|}{ The Pre-Eruption Place of Residence $(n)$} & $\begin{array}{c}\text { Interested in Participating in Disaster } \\
\text { Microinsurance }\end{array}$ \\
\hline \multicolumn{3}{|c|}{ 1. In disaster-prone area (self assessment)? } \\
\hline Yes & 175 & $52(30 \%)$ \\
\hline No & 96 & $23(24 \%)$ \\
\hline \multicolumn{3}{|c|}{ 2. In Hazard Zone III? } \\
\hline Yes & 204 & $59(29 \%)$ \\
\hline No & 67 & $16(24 \%)$ \\
\hline \multicolumn{3}{|c|}{ 3. In directly affected area? } \\
\hline Yes & 170 & $46(27 \%)$ \\
\hline No & 101 & $29(29 \%)$ \\
\hline \multicolumn{3}{|c|}{ 4. (1) match with (2) } \\
\hline Yes-Yes & 166 & $48(29 \%)$ \\
\hline No-No & 58 & $12(21 \%)$ \\
\hline \multicolumn{3}{|c|}{ 5. (1) match with (3) } \\
\hline Yes-Yes & 141 & $38(27 \%)$ \\
\hline No-No & 67 & $15(22 \%)$ \\
\hline
\end{tabular}

With regard to insurance literacy, we create a simple index representing the respondents' general knowledge about insurance. This index consists of respondents' knowledge of basic definitions about insurance, their knowledge about their insurance company, and their experience of insurance products (see Appendix B).

We find that a higher level of insurance literacy consistently increases the interest in disaster microinsurance (Table 2). However, this table also shows that more than 50\% of the respondents had no insurance literacy. Figure 3 shows that 'unfamiliar with the 
procedure of insurance' is the most important reason for respondents who are not interested in disaster microinsurance. It is followed by a presumption that insurance is costly, and that insurance is for rich people only. This result indicates that it is important to develop insurance literacy in order to implement microinsurance for people living in disaster-prone areas. A lack of insurance literacy may limit the use of disaster microinsurance as an option in dealing with negative natural shocks.

Table 2. Response to disaster microinsurance based on insurance literacy.

\begin{tabular}{cccc}
\hline \multirow{2}{*}{$\begin{array}{c}\text { Insurance } \\
\text { Literacy }\end{array}$} & \multicolumn{2}{c}{$\begin{array}{c}\text { Interested in Participating in Hypothetical } \\
\text { Disaster Microinsurance (\%) }\end{array}$} & \multirow{2}{*}{ Total (\%) } \\
\cline { 2 - 3 } & No & Yes & \\
\hline Illiterate & 43.91 & 10.33 & 54.24 \\
Low & 16.24 & 7.38 & 24.62 \\
Moderate & 7.75 & 5.90 & 14.65 \\
High & 4.43 & 4.06 & 8.49 \\
\hline Total & 72.32 & 27.68 & 100.00 \\
\hline
\end{tabular}

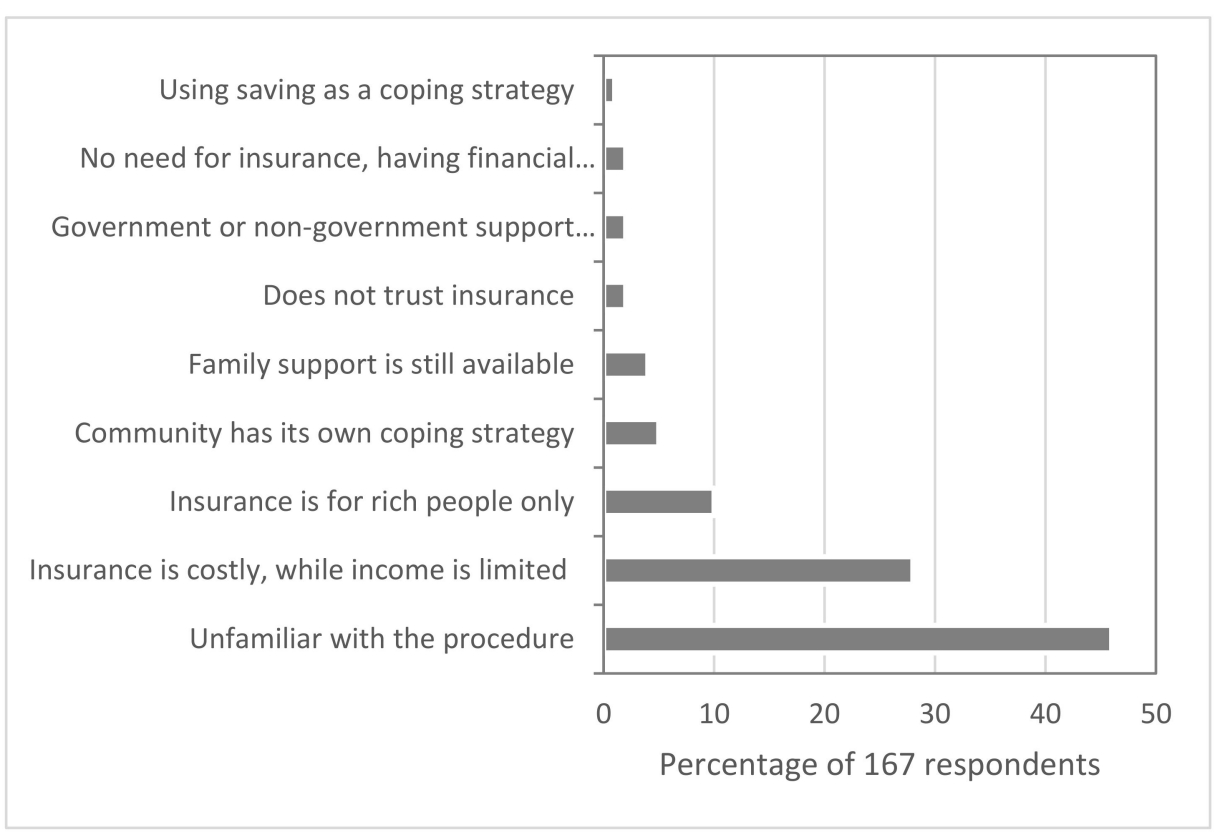

Figure 3. Reasons for not being interested in participating in disaster microinsurance selected by respondents.

\subsection{Logit Model}

We use logit regression to investigate the determinants of demand for this microinsurance in the context of the eruption risks of the Merapi volcano. Our variable of interest is disaster risk perception. The following logit model will be used:

$$
L_{i}=\ln \left[P /\left(1-P_{i}\right)\right]=\beta_{0}+\beta_{1} R_{i}+\Sigma \beta_{k} X_{k, i}+\varepsilon_{i}
$$

where $P_{i}$ is the probability of respondent $\mathrm{i}$ being interested in participating in a (hypothetical) disaster microinsurance scheme; $R$ represents eruption risk perception (a dummy variable); $X_{k}$ represents a range of $k$ other relevant variables; and $\varepsilon$ is the error term.

There are three alternative dummy variables for $R$, the household's perception of risk: their place of residence was in a disaster-prone area (DPA), living in hazard zone III (HZ3), or living directly affected Area $(D A)$. Other relevant variables include: 
- insurance literacy (IL), a simple index representing the respondents' general knowledge about insurance based on three elements (see Appendix B);

- the ratio of the number of household members under the age of 18 to household size $(C R)$;

- a proxy for health status which is the ratio of the length of the period of smoking consumption to the age of the head of the household (SR);

- four indicators of local social networks indicating the disaster-coping ability: a dummy variable for households that have relatives who are known as village officials $(R O)$, dummy variables for membership of two types of associations: farmer associations $(F A)$ and breeder associations $(B A)$ - since agriculture and livestock are important activities for villagers-and a dummy variable indicating whether a household had access to disaster relief for housing $(H R)$;

- a dummy variable for liquid assets, such as cash, savings, or deposits in bank accounts $(L A)$; and

- monthly income per person (in $\log$ form, $\log P Y M$ ).

Summary statistics are presented in Table 3.

Table 3. Reasons for not being interested in participating in disaster microinsurance.

\begin{tabular}{|c|c|c|c|c|c|c|}
\hline Notation & Variable & Description $^{1}$ & $\%$ & Mean & Median & $\begin{array}{l}\text { Std. } \\
\text { Dev. }\end{array}$ \\
\hline PI & $\begin{array}{l}\text { Interested in } \\
\text { participating }\end{array}$ & $\begin{array}{l}\text { Respondent was interested in participating in } \\
\text { disaster microinsurance (D) }\end{array}$ & 0.28 & & & \\
\hline$D P A$ & $\begin{array}{l}\text { Disaster-Prone } \\
\text { Area }\end{array}$ & Place of residence was in disaster-prone area (D) & 0.65 & & & \\
\hline HZ3 & Hazard Zone III & $\begin{array}{l}\text { Place of residence was in the Hazard Zone III (D) } \\
\text { (see: Appendix A) }\end{array}$ & 0.75 & & & \\
\hline$D A$ & $\begin{array}{c}\text { Directly } \\
\text { Affected Area }\end{array}$ & $\begin{array}{c}\text { Place of residence was in the Directly Affected } \\
\text { Area (D) (see: Appendix A) }\end{array}$ & 0.63 & & & \\
\hline$I L$ & $\begin{array}{l}\text { Insurance } \\
\text { literacy }\end{array}$ & $\begin{array}{l}\text { Mean average of three dummy variables for } \\
\text { insurance knowledge (see: Appendix B) }\end{array}$ & & 0.25 & 0.50 & 0.33 \\
\hline$C R$ & Children & $\begin{array}{c}\text { Ratio of the number of children below } 18 \text { years to } \\
\text { household size }\end{array}$ & & 0.22 & 0.38 & 0.22 \\
\hline$S R$ & Smoking risk & $\begin{array}{l}\text { Ratio of the length of smoking consumption } \\
\text { period of household head to her/his age }\end{array}$ & & 0.21 & 0.44 & 0.26 \\
\hline$R O$ & Relatives & $\begin{array}{l}\text { Household has relatives who are village } \\
\text { officials (D) }\end{array}$ & 0.11 & & & \\
\hline$F A$ & $\begin{array}{l}\text { Farmer } \\
\text { associations }\end{array}$ & Member of farmer associations (D) & 0.36 & & & \\
\hline$B A$ & $\begin{array}{l}\text { Breeder } \\
\text { associations }\end{array}$ & Member of breeder associations (D) & 0.38 & & & \\
\hline$H R$ & House relief & Household received house relief (D) & 0.35 & & & \\
\hline$L A$ & Liquid assets & Household has liquid assets (D) & 0.69 & & & \\
\hline $\log P Y M$ & Income (log) & log of household monthly income/person (Rp) & & 5.40 & 4.95 & 0.60 \\
\hline
\end{tabular}

\section{Results and Discussion}

This section presents the results of our empirical analysis of the determinants of the probability of participating in disaster microinsurance. We provide three alternative models in which we use respondents' perception of risk and two other indicators of risk that represent risk from the experts' perspective. The sign of the regression coefficients in these three models is basically the same. The main difference is that these experts' perceptions of risk indicators do not have a statistically significant influence on the participation in disaster microinsurance. On the other hand, insurance literacy and membership in farmer associations are always significantly correlated with the probability to participate 
in disaster microinsurance. We should note that the pseudo R-squared is relatively small. One possible explanation is due to the fact that an actual disaster microinsurance scheme has not been developed for the Merapi eruption risk. This prevents the study to exploring other important variables such as insurance premium and its benefits. Given this limitation, we then discuss the first model.

Table 4, Column (1), shows that the respondent's perception of natural hazard risks shows statistically significant effects on the probability of being interested in participating in a disaster microinsurance scheme. This suggests that people's perception of volcanic risk has a positive influence on the probability of participating in a disaster microinsurance scheme. This finding is relatively in line with a previous study in China [13,20]. The positive influence of risk perception also indicates that respondents are aware of important strategies, of which disaster microinsurance is a promising option. In this context, participating in a disaster microinsurance can be identified as a protective behavior; that is, to protect the households, their quality of life and wealth, from negative implications of possible eruptions in the future.

Table 4. Determinants of participation in disaster microinsurance.

\begin{tabular}{|c|c|c|c|}
\hline Variable $^{1}$ & 1 & 2 & 3 \\
\hline Disaster-Prone Area (self assessment) & $\begin{array}{l}0.57 * \\
(0.34)\end{array}$ & & \\
\hline Hazard Zone III (expert assessment) & & $\begin{array}{c}0.56 \\
(0.41)\end{array}$ & \\
\hline Directly Affected Area (expert assessment) & & & $\begin{array}{c}0.18 \\
(0.33)\end{array}$ \\
\hline Insurance Literacy & $\begin{array}{c}1.69 \text { *** } \\
(0.47)\end{array}$ & $\begin{array}{c}1.75^{* * *} \\
(0.46)\end{array}$ & $\begin{array}{c}1.68^{* * *} \\
(0.46)\end{array}$ \\
\hline Children & $\begin{array}{c}0.44 \\
(0.68)\end{array}$ & $\begin{array}{c}0.48 \\
(0.68)\end{array}$ & $\begin{array}{c}0.46 \\
(0.68)\end{array}$ \\
\hline Smoking Risk & $\begin{array}{l}0.96 \text { * } \\
(0.58)\end{array}$ & $\begin{array}{c}0.90 \\
(0.58)\end{array}$ & $\begin{array}{l}0.97 * \\
(0.58)\end{array}$ \\
\hline Relatives & $\begin{array}{l}-0.18 \\
(0.48)\end{array}$ & $\begin{array}{l}-0.29 \\
(0.49)\end{array}$ & $\begin{array}{c}-0.24 \\
(0.48)\end{array}$ \\
\hline Farmer Association & $\begin{array}{c}-0.61 \text { * } \\
(0.34)\end{array}$ & $\begin{array}{c}-0.61 \text { * } \\
(0.34)\end{array}$ & $\begin{array}{c}-0.69 * * \\
(0.33)\end{array}$ \\
\hline Breeder Association & $\begin{array}{l}0.60 * \\
(0.32)\end{array}$ & $\begin{array}{c}0.53 \\
(0.33)\end{array}$ & $\begin{array}{l}0.61 * \\
(0.32)\end{array}$ \\
\hline House Relief & $\begin{array}{c}-0.69^{* *} \\
(0.34)\end{array}$ & $\begin{array}{c}-0.60 * \\
(0.34)\end{array}$ & $\begin{array}{l}-0.51 \\
(0.34)\end{array}$ \\
\hline Liquid Assets & $\begin{array}{l}-0.32 \\
(0.33)\end{array}$ & $\begin{array}{l}-0.26 \\
(0.33)\end{array}$ & $\begin{array}{c}-0.28 \\
(0.33)\end{array}$ \\
\hline Log (Income/Person) & $\begin{array}{l}-0.21 \\
(0.28)\end{array}$ & $\begin{array}{l}-0.13 \\
(0.29)\end{array}$ & $\begin{array}{l}-0.15 \\
(0.28)\end{array}$ \\
\hline Constant & $\begin{array}{l}-0.58 \\
(1.44)\end{array}$ & $\begin{array}{l}-1.12 \\
(1.54)\end{array}$ & $\begin{array}{l}-0.69 \\
(1.48)\end{array}$ \\
\hline Pseudo R-squared & 0.096 & 0.094 & 0.088 \\
\hline Log lik. & -144 & -145 & -146 \\
\hline Wald chi-squared & 25.36 & 27.88 & 25.98 \\
\hline Correctly classified (\%) & 73.06 & 73.43 & 74.91 \\
\hline$n$ & 271 & 271 & 271 \\
\hline
\end{tabular}

${ }^{1}$ The dependent variable is 'Interested in participating in disaster microinsurance' (1 = Yes; $0=$ No). RSE (robust standard errors) are in parentheses. ${ }^{*}$ significant at the $10 \%$ level; ${ }^{* *}$ significant at the $5 \%$ level; ${ }^{* * *}$ significant at the $1 \%$ level.

The result also shows that insurance literacy has a large influence on the probability of a respondent being interested in participating in disaster microinsurance. This result confirms the important role of insurance literacy in affecting the probability of households being interested in participating in a disaster microinsurance scheme (see, e.g., [20]). It also 
implies that it is important to develop insurance literacy in order to increase the rate of participation in disaster microinsurance.

We also find that the smoking risk variable, as a proxy of health risk, positively affects the respondent's probability of being interested in participating in disaster microinsurance. A higher value of the smoking indicator indicates a higher health risk, and volcanic eruptions increase this health risk.

With regard to local social networks as indicators of disaster-coping ability, the result shows that respondents who are members of farmer associations tend to have a low probability of being interested in participating in disaster microinsurance. This result confirms the negative influence of membership in a local association as found in Gine et al. [38]. The negative effect of membership in farmer associations supports the argument that this local association plays an alternative role for villagers to cope with the impact of volcanic eruption. This causes disaster microinsurance to be less important. The farmer association may also play a role as a channel for the delivery of disaster relief specifically allocated to restoring farming activities in this area, but a different role is found for membership in breeder associations. Being a member of a breeder association increases the probability of being interested in participating in disaster microinsurance. One possible reason for this difference is that breeding activities - including the rearing of dairy cows-have a relatively important role, in terms of their economic value, compared with traditional farming for villagers in the Merapi area. It is also possible that breeder associations are better organized than the farmer associations.

As expected, access to house disaster relief negatively influences respondents' interest in participating in disaster microinsurance. This means that respondents who have access to house relief tend to have a low probability of accepting disaster microinsurance. This finding is also in line with the finding by Wang et al. [20]. House relief is usually provided by the government and so is seen as a disaster-coping mechanism.

Overall, the findings suggest that the important variables are the perception of natural disaster risks, insurance literacy, health risk, and local social networks (memberships of farmer and breeder associations, and access to house relief).

\section{Conclusions}

The main objective of this paper was to investigate the influence of the perception of natural hazard risks on the probability of a respondent being interested in participating in a disaster microinsurance scheme. This microinsurance scheme is particularly designed to improve people's resilience toward natural hazards. We use household data containing people's willingness to take a hypothetical disaster microinsurance scheme to assess a specific disaster risk perception, notably the risk of an eruption of Mount Merapi in Yogyakarta, Indonesia. This study can provide some early evidence on this prospective countermeasure of natural hazard risks.

On the basis of a logit model, we find that the respondents' perception of natural hazard risks positively influences their interest in participating in disaster microinsurance. This result also suggests that households living in disaster-prone areas are aware of the risks of their location. This awareness then increases the probability of a respondent being interested in participating in disaster microinsurance as a tool to minimize the impact of natural disasters. It implies that local people's perception of natural disaster risks should be taken into account in designing and proposing a specific insurance scheme for people living in areas vulnerable to natural hazard events. This argument is aligned with results from several previous studies for different cases, such as those by Xu et al. [13], in the case of the 2008 Wenchuan earthquake, and by Royal and Walls [14], in the case of Maryland floodplain.

We also find that insurance literacy has a strong positive relationship with the respondents' interest in participating in disaster microinsurance. The large effect of insurance literacy implies that it is important to develop insurance literacy in order to increase the rate of participation in disaster microinsurance. Whether respondents showed an interest 
in participating in disaster microinsurance is also determined by their local networksmeasured by the access to house relief and membership in local associations-and health risk that is related to smoking behavior. We conclude that these variables should also be considered when studying and implementing microinsurance schemes as a formal coping strategy for people living in disaster-prone areas. It should be noted that an actual disaster microinsurance scheme has not been developed for the Merapi eruption risk, which prevents the study from exploring other variables such as insurance premium and its benefits.

The practical implication of this study is that there is a good chance to promote and implement a disaster microinsurance in Indonesian volcano eruption-prone areas, particularly in the Merapi region. Households living in this area are relatively aware of the eruption risks. Nevertheless, it is important for the government, especially at the village level, to continuously improve people's insurance literacy. Village governments and local agencies for disaster management may want to collaborate with insurance companies in developing activities to strengthen people's insurance literacy and incorporate these activities into the existing program, called disaster resilient village (Desa Tangguh Bencana).

Finally, it should be noted that many natural hazards regularly occur in Indonesia and the surrounding regions. A volcanic eruption is only one of them. Although results in this paper can certainly serve as inputs toward developing microinsurance schemes for other natural hazards, more research is still needed to confirm the applicability of the results in this paper to other cases.

Author Contributions: Conceptualization, A.G.B., P.R. and B.P.R.; methodology, A.G.B., H.L.F.d.G., P.R., B.P.R. and W.Z; formal analysis, A.G.B.; data collection, A.G.B. and B.P.R.; writing-original draft preparation, A.G.B.; writing - review and editing, A.G.B., H.L.F.d.G., B.P.R. and W.Z.; visualization, A.G.B. and B.P.R.; funding acquisition, A.G.B., P.R. and B.P.R. All authors have read and agreed to the published version of the manuscript.

Funding: This research was funded by Republic of Indonesia from the Indonesian Directorate General of Higher Education under a scholarship for A.G.B, and a support from Atma Jaya Yogyakarta University. Data collection was funded by the Australian National University (ANU)'s Indonesia Project.

Institutional Review Board Statement: Not applicable.

Informed Consent Statement: Not applicable.

Data Availability Statement: The data presented in this study are available on request from the corresponding author.

Acknowledgments: Aloysius Gunadi Brata, Henri L. F. de Groot, Budy P. Resosudarmo and Wouter Zant dedicate this article to the memory of Piet Rietveld, who, sadly, passed away on 1 November 2013, after a short illness. We would like to thank Danang Darmawan of Gadjah Mada University for coordinating the household survey for this paper, and Aryanto Steyn of BPBD DI Yogyakarta for sharing useful information about the current situation of the Merapi volcano.

Conflicts of Interest: The authors declare no conflict of interest.

\section{Appendix A. Constructing Indicators of Disaster Risk Perception}

The respondents' perception of risk is based on their response to the question: 'Was your place of residence in a disaster-prone area (for any natural hazard events)?'. This question assessed their place of residence during the 2010 Merapi eruption. Therefore, their response may indicate the respondents' disaster risk perception in their former place of residence. Based on their response, we classified respondents into two groups of risk perception: 'living in disaster-prone area' and 'not living in disaster-prone area'. These indicators can be considered as lay people's judgements of disaster risks [19].

The following is how we check the validity and reliability of our method classifying respondents' risk perceptions. In response to the large 2010 eruption, the Center of Volcanology and Geological Hazard Mitigation (CVGHM) updated the Merapi Hazard 
Map. The map shows three hazard zones: hazard zone I (HZ I), hazard zone II (HZ II), and hazard zone III (HZ III). The most dangerous zone is HZ III. There are two sub-areas in this zone: the areas directly affected (DA) and indirectly affected (IA) by the eruptions. Subvillages in HZ III were then identified by the government of the Sleman district [15]. These sub-villages were also classified into two categories: totally affected and partly affected. Based on the hazard zone classification, DA is clearly the most dangerous area. The development policies of DA are as follows: (1) this area is not recommended for human settlements; (2) this area is highly recommended for forestry, as a conservation area, and for eco-tourism; (3) infrastructures in this area are provided to support the conservation area, eco-tourism, and disaster mitigation. The zero-growth policy also applies to zone IA. Zone II is planned to become an area for limited expansion with strict land use control. Zone I is safer than zone II, but the risk of a lava flood cannot be excluded.

The results of classifying respondents' risk perceptions are presented in Table A1 for all respondents (Panel A) and for the Cangkringan subdistrict only (Panel B). Panel A shows that the experts' risk assessments based on the Merapi Hazard Map are in line with the respondents' risk perception. The matching rate of risk perceptions is $83 \%$ and $77 \%$ for HZ III and DA, respectively. We also provide a cross-tabulation only for those respondents from the Cangkringan subdistrict, since this is close to the source of volcanic risk. The results are presented in Panel B. As we can see, there are no significant differences in the matching rates between Panel B and Panel A. Overall, the high matching rates reported in the table suggest that the respondents' perceptions of risk are in line with the experts perceptions of risk. We hence argue that our method to measure risk perception is relatively valid and reliable [39].

Table A1. Pre-eruption place of residence: experts' assessment and respondents' perception ${ }^{1}$.

\begin{tabular}{|c|c|c|c|}
\hline \multirow[t]{2}{*}{$\begin{array}{l}\text { Assessment of Risk } \\
\text { by Using the Hazard Map }\end{array}$} & \multicolumn{3}{|c|}{$\begin{array}{l}\text { Respondents' Perception of Risk } \\
\text { (Disaster-Prone Area) }\end{array}$} \\
\hline & No & Yes & Total \\
\hline \multicolumn{4}{|c|}{$\begin{array}{l}\text { Panel A: Cangkringan and Prambanan }(\mathrm{N}=271) \\
\text { Hazard Zone III: }\end{array}$} \\
\hline -No & 58 & 9 & 67 \\
\hline -Yes & 38 & 166 & 204 \\
\hline $\begin{array}{l}\text {-Matching rate (\%) } \\
\text { Directly Affected Area: }\end{array}$ & & 82.66 & \\
\hline$-\mathrm{No}$ & 67 & 34 & 101 \\
\hline -Yes & 29 & 141 & 170 \\
\hline -Matching rate $(\%)$ & & 76.75 & \\
\hline \multicolumn{4}{|c|}{$\begin{array}{l}\text { Panel B: Cangkringan }(\mathrm{N}=211) \\
\text { Hazard Zone III: }\end{array}$} \\
\hline -No & 0 & 7 & 7 \\
\hline -Yes & 38 & 166 & 204 \\
\hline $\begin{array}{l}\text {-Matching rate (\%) } \\
\text { Directly Affected Area: }\end{array}$ & & 78.67 & \\
\hline -No & 9 & 32 & 41 \\
\hline -Yes & 29 & 141 & 170 \\
\hline -Matching rate $(\%)$ & & 71.09 & \\
\hline
\end{tabular}




\title{
Appendix B. Constructing the Indicator of Insurance Literacy
}

The section of the disaster microinsurance in the questionnaire begins with a description about insurance in general, followed by a question with four possible answers to assess respondents' knowledge about insurance (see: Table A2). A description of disaster microinsurance is then presented.

Table A2. Definition and questions related to the knowledge of insurance and participation in disaster microinsurance.

\begin{abstract}
Basic definition of insurance:
Insurance is a type of protection for people who face exposure or certain risk where they pay a certain amount of money according to the probability of the exposure or risk. The policy holders will be compensated in accordance with the insurance agreement if their losses have been formally identified through investigation.
\end{abstract}

\section{Perception of insurance:}

In your opinion, the right statement about insurance is (choose the best one):

1. A policy holder will have to pay a certain amount of money regularly for insurance in order to anticipate unexpected events in the future.

2. Receiving a certain amount of money from an insurance company means that we receive financial aid from an insurance company.

3. Insurance is a type of savings or investment, in which we deposit our savings regularly.

4. Insurance is a type of collateral for applying credit to a commercial bank.

Identifying insurance companies:

Please mention the name of an insurance company. (open-ended question)

\section{Experience with insurance products:}

Does your household have experience of insurance products (for instance, life insurance, health insurance, insurance for vehicles)?

\section{Description of disaster microinsurance:}

The main aim of disaster microinsurance is to protect low-income people from certain natural hazards, where people pay a fixed premium according to the likely occurrence of natural hazards and their risk. The insurance targets people who do not have access to conventional insurance or public schemes. The basic principle of disaster microinsurance is that, if participants have regularly paid a certain amount of disaster insurance premium, they will get compensation for their losses that have been officially identified due to a natural disaster.

\section{Need insurance as a protection:}

In your opinion, do you need insurance to protect your household from the risk of a natural disaster that you have mentioned?

\section{Willingness to participate in disaster microinsurance:}

By considering your experience with the Merapi eruption in 2010 and your financial position, are you interested in participating in disaster microinsurance programs?

These steps are implemented in the survey in order to minimize measurement errors. The surveyors explained what insurance is and re-explained it for respondents who still did not understand the explanation. The meaning of disaster microinsurance was also explained to respondents before the surveyors asked further questions. Since the study focuses on microinsurance for natural disaster risks, the survey also assessed the main concern of respondents based on their experience of the 2010 Merapi eruption, by choosing one of six possible impacts of this eruption (house damaged; crop damaged; cattle killed or lost; health problems; unemployment problems; and children's education). This strategy was used to link questions on insurance to the context of disaster risks.

We then constructed a simple index representing the respondents' general knowledge about insurance based on three elements. These elements are: (1) whether a respondent was 
able to choose the correct answer to a question about the basic description of insurance (see 'perception of insurance' in Table A2); (2) whether a respondent was able to mention at least one name of an insurance company ('identifying insurance companies' in Table A2); and (3) whether a respondent had experience of insurance products ('experience with insurance products' in Table A2). Specifically for the first element, the correct answer is the first option. These three elements are in binary values. The correlation between element (1) and (2), (1) and (3), and (2) and (3) of insurance literacy are 0.39, 0.23, and 0.58, respectively. Those respondents who chose the correct option of perception of insurance, can correctly identify names of insurance companies, and also had experience with insurance products, are then classified as having high insurance knowledge. When respondents do not answer correctly, and they had no experience with any insurance products, we classified them as having no insurance knowledge. These criteria result in four levels of insurance literacy: illiterate, low, moderate, high. The survey then delivered a question to determine whether respondents would be interested in participating in disaster microinsurance in view of their experiences with the eruption of the Merapi volcano in 2010, as well as, of their financial situation. This question is preceded by a question to determine whether respondents need insurance as a protection against natural disaster risks. The justification for using this step is that only those respondents who need insurance might be interested in participating in disaster microinsurance.

\section{References}

1. Cohen, M.; Sebstad, J. The demand for microinsurance. In Protecting the Poor-A Microinsurance Compendium; Churchill, C., Ed.; Munich Re Foundation: Munich, Germany, 2006; pp. 25-44.

2. Heydel, T.; Ruff, S.; Ramm, G.; Wilhelm, M. Need Assessment and Feasibility Study on Disaster Microinsurance: Empirical Findings from Four Province in Indonesia; GTZ: Eshborm, Germany, 2009.

3. Morelly, E.; Onnis, G.A.; Ammann, W.J.; Sutter, C. (Eds.) Microinsurance, An Innovative Tool for Risk and Disaster Management; Global Risk Forum: Davos, Switzerland, 2010.

4. Platteau, J.P.; De Bock, O.; Gelade, W. The demand for microinsurance: A literature review. World Dev. 2017, 94, 139-156. [CrossRef]

5. Mechler, R.; Linnerooth-Bayer, J.; Peppiatt, D. Disaster Insurance for the Poor? A Review of Microinsurance for Natural Disaster Risks in Developing Countries; ProVention/IIASA: Geneva, Switzerland; Laxenburg, Austria, 2006. Available online: https: //www.preventionweb.net/publications/view/2059 (accessed on 3 January 2013).

6. World Bank. Indonesia: Advancing a National Disaster Risk Financing Strategy-Options for Consideration; World Bank: Washington, DC, USA, 2011. Available online: https:/ / openknowledge.worldbank.org/handle/10986/22421 (accessed on 3 January 2013).

7. World Bank. Advancing Disaster Risk Financing and Insurance in ASEAN Member States: Framework and Option for Implementation; World Bank: Washington, DC, USA, 2012. Available online: https://openknowledge.worldbank.org/handle/10986/12627 (accessed on 3 January 2013).

8. Rianti, R.; Sunanta, A.; Faradynawati, I.A.A. A Study on Demand for Micro Insurance for Low-Income Households in DisasterProne Areas of Indonesia; Department of Management Working Paper; Faculty of Economic University of Indonesia: Jakarta, Indonesia, 2011.

9. Reinhard, D. Potential and limitations of microinsurance for protecting the poor. In Climate Change, Justice and Sustainability: Linking Climate and Development Policy; Edenhofer, O., Wallacher, J., Lotze-Campen, H., Reder, M., Knopf, B., Müller, J., Eds.; Springer: Dordrecht, The Netherlands, 2012; pp. 227-237.

10. Churchill, C. Trying to understand the demand for microinsurance. J. Int. Dev. 2002, 14, 381-387. [CrossRef]

11. Matul, M.; Dalal, A.; De Bock, O.; Gelade, W. Why People do not buy microinsurance and what can we do about it. In Microinsurance Innovation Facility Microinsurance Paper No. 20; International Labor Office: Geneva, Switzerland, 2013.

12. Eling, M.; Pradhan, S.; Schmit, J.T. The determinants of microinsurance demand. Geneva Pap. 2014, 39, 224-263. [CrossRef]

13. Xu, D.; Liu, E.; Wang, X.; Tang, H.; Liu, S. Rural households' livelihood capital, risk perception, and willingness to purchase earthquake disaster insurance: Evidence from Southwestern China. Int. J. Environ. Res. Public Health 2018, 15, 1319. [CrossRef]

14. Royal, A.; Walls, M. Flood risk perceptions and insurance choice: Do decisions in the floodplain reflect overoptimism? Risk Anal. 2019, 39, 1088-1104. [CrossRef] [PubMed]

15. Brown, P.; Daigneault, A.J.; Tjernström, E.; Zou, W. Natural disasters, social protection, and risk perceptions. World Dev. 2018, 104, 310-325. [CrossRef] [PubMed]

16. Subandriyo. Sejarah erupsi gunung Merapi dan dampaknya terhadap Kawasan Borobudur [The history of the Merapi eruption and its impact on the Borobudur area]. In Menyelamatkan Candi Borobudur dari Erupsi Merapi [Save Borobudur Temple from the Merapi Eruption]; Sutopo, M., Ed.; Balai Konservasi Peninggalan Borobudur: Magelang, Indonesia, 2011; pp. 86-96. 
17. Surono, N.; Jousset, P.; Pallister, J.; Boichu, M.; Buongiorno, M.F.; Budisantoso, A.; Costa, F.; Andreastuti, S.; Prata, F.; Schneider, D.; et al. The 2010 explosive eruption of Java's Merapi volcano-A '100-year' event. J. Volcanol. Geotherm. Res. 2012, 241-242, 121-135. [CrossRef]

18. Bappenas, B.N.P.B. Rencana aksi rehabilitasi dan rekonstruksi pascabencana erupsi gunung merapi provinsi D.I. yogyakarta dan provinsi jawa tangah tahun 2011-2013. In The Action Plan for Rehabilitation and Reconstruction in Post-Eruption of the Merapi Volcano in the Province of DI Yogyakarta and Central Java, 2011-2013; Bappenas and BNPB: Jakarta, Indonesia, 2011.

19. Brown, V.J. Risk perception: It's personal. Environ. Health Perspect. 2014, 122, A276-A279. [CrossRef] [PubMed]

20. Wang, M.; Yang, S.; Zhao, W.; Liu, M.; Shi, P. Are people willing to buy natural disaster insurance in China? Risk awareness, insurance acceptance, and willingness to pay. Risk Anal. 2012, 32, 1717-1740. [CrossRef] [PubMed]

21. Brilly, M.; Polic, M. Public perception of flood risks, flood forecasting and mitigation. Nat. Hazards Earth Syst. Sci. 2005, 5, 345-355. [CrossRef]

22. Siegrist, M.; Gutscher, H. Flooding risks: A comparison of lay people's perceptions and expert's assessments in Switzerland. Risk Anal. 2006, 26, 971-979. [CrossRef] [PubMed]

23. Slovic, P. Perception of risk. Science 1987, 236, 280-285. [CrossRef] [PubMed]

24. Renn, O. Perception of risks. Geneva Pap. Risk Insur. Issues Pract. 2004, 29, 102-114. [CrossRef]

25. Renn, O. Perception of risks. Toxicol. Lett. 2004, 149, 405-413. [CrossRef] [PubMed]

26. Brody, S.D.; Highfield, W.; Alston, L. Does location matter? Measuring environmental perceptions of creeks in two San Antonio Watersheds. Environ. Behav. 2004, 36, 229-250. [CrossRef]

27. Brody, S.D.; Zahran, S.; Vedlitz, A.; Grower, H. Examining the relationship between physical vulnerability and public perceptions of global climate change in the United States. Environ. Behav. 2008, 40, 72-95. [CrossRef]

28. Kelman, I.; Mather, T.A. Living with volcanoes: The sustainable livelihoods approach for volcanoes-related opportunities. J. Volcanol. Geotherm. Res. 2008, 172, 189-198. [CrossRef]

29. Fier, S.G.; Carson, J.M. Catastrophes and the demand for life insurance. J. Insur. Issues 2015, 38, 125-156. [CrossRef]

30. Akter, S.; Brouwer, R.; van Beukering, P.J.H.; French, L.; Silver, E.; Choudhury, S.; Aziz, S.S. Exploring the feasibility of private micro flood insurance provision in Bangladesh. Disasters 2011, 35, 287-307. [CrossRef]

31. Naoi, M.; Seko, M.; Sumita, K. Community rating, cross subsidies and underinsurance: Why so many households in Japan do not purchase earthquake insurance. J. Real Estate Financ. Econ. 2010, 40, 544-561. [CrossRef]

32. Longwell, T. An. Empirical Examination of Demand for Earthquake Insurance in California; University of Minnesota: Minneapolis, MN, USA, 2013.

33. McCormack, L.A.; Garfinkel, S.A.; Hibbard, J.H.; Keller, S.D.; Kilpatrick, K.E.; Kosiak, B. Health insurance knowledge among medicare beneficiaries. Health Serv. Res. 2002, 37, 41-61. [CrossRef]

34. Paez, K.A.; Mallery, C.J.; Noel, H.; Pugliese, C.; Mcsorley, V.E.; Lucado, J.L. Development of the health insurance literacy measure (HILM): Conceptualizing and measuring consumer ability to choose and use private health insurance. J. Health Commun. 2014, 19, 225-239. [CrossRef] [PubMed]

35. Alam, M.J.; Naasnen, M.; Chowdhury, F.S. Demand for Weather Index Based Microinsurance in Coastal Areas of Bangladesh. In Proceedings of the European Association of Environmental and Resource Economists 18th Annual Conference, Rome, Italy, 29 June-2 July 2011.

36. Vidyattama, Y.; Miranti, R.; Resosudarmo, B.P. The role of health insurance membership in health service utilisation in Indonesia. Bull. Indones. Econ. Stud. 2014, 50, 393-413. [CrossRef]

37. Takasaki, Y. Do local elites capture natural disaster reconstruction funds? J. Dev. Stud. 2011, 47, 1281-1298. [CrossRef]

38. Gine, X.; Karlan, D.; Ngatia, M. Social networks, financial literacy, and index insurance. In Proceedings of the Northeast Universities Development Consortium (NEUDC) Conference, New Haven, CT, USA, 12-13 November 2011. Available online: https:/ / www.dartmouth.edu/neudc2012/docs/paper_183.pdf (accessed on 5 January 2013).

39. Man, S.S.; Chan, A.H.S.; Alabdulkarim, S. Quantification of risk perception: Development and validation of the construction worker risk perception (CoWoRP) scale. J. Saf. Res. 2019, 71, 25-39. [CrossRef] [PubMed] 